\title{
Predicting Future Performance Through Selection Methods
}

\author{
Ira Irawati \\ Departement of Public Administration \\ Universitas Padjadjaran \\ Sumedang, Indonesia \\ ira.irawati@unpad.ac.id
}

\author{
Nunung Runiawati \\ Departement of Public Administration \\ Universitas Padjadjaran \\ Sumedang, Indonesia \\ n.runiawati@unpad.ac.id
}

\author{
Rina Hermawati \\ Departement of Antrophology \\ Universitas Padjadjaran \\ Sumedang, Indonesia \\ rina.antrop@gmail.com
}

\begin{abstract}
One of the demands of bureaucratic reform in Indonesia is the improvement of the professionalism of state civil apparatus (ASN). In order to obtain professional human resources, the government has implemented a competency-based selection method. This paper would identify advantages and disadvantages of the selection method in predicting the future performance of state civil apparatus. This research used the qualitative method. The selection method with the highest validity is able to predict the future performance of employees. However, the determination of types of competence tests must also consider the cost of selection and the flexibility of the measures towards various kinds of jobs. Psychological tests have some advantages as a measure, both in cost and validity, compared to interviews and competence questionnaires. As for the choice of the method of simulation, In-Tray has advantages compared to other techniques of simulation because it is able to measure six types of competences and relatively easy to perform.
\end{abstract}

Keywords: bureacratic reform; performance; selection method

\section{INTRODUCTION}

One of the demands of bureaucratic reform in Indonesia is the improvement of the professionalism of state civil apparatus (ASN). Ever since, the government started to feel some concern about the implementation of the principle of merit system in the management of employees in order to guarantee state civil apparatus' professionalism. In fact, Law on State Civil Apparatus of 2014 explicitly explains the implementation of merit system in each stage of civil service.

However, the implementation of merit system is obstructed by some problems, among other things, job assessment which has not yet been conducted objectively; low work culture and work ethic, and inconsistent imposition of disciplinary regulations [1]. One of the reasons that these phenomena occur to civil servants is informal social relationship between an employee and another employee, particularly the closeness to other employees who have a high position, which may influence the policy on the placement of an employee in a particular job position. The result of studies conducted by Erman (2007) and Agusyanto (2007) has stated various forms of social relationship which influence the position of a civil servant, among other things, political relationship between local leaders and their followers, colleagues from the same university, kinship, and friendship.
These forms of relationship have made employees' career become uncertain.

In order to obtain professional human resources, the government has implemented competence assessment methods which are conducted during the recruitment process of new employees and determination of structural officials of Echelons I-IV. Regulation of Head of the National Civil Service Agency (BKN) Number 23 Year 2011 on Guideline on Competence Assessment of Civil Servants has stipulated a number of methods for measuring competence, such as psychological test, competence interviews, competence questionnaires, and assessment centers. The research question of this paper is what are advantages and disadvantages of each type of measures? This paper would identify advantages and disadvantages of the selection method in predicting the future performance of state civil apparatus.

\section{RESEARCH METHOD}

This research used the qualitative method. The type of data used in this research is a combination of primary data and secondary data. Primary data were obtained through the research experience, while secondary data were obtained from literature study.

Data were collected from multiple sources, such as interviews, observations participatory, and literature reviews. In this way, the combination of data collection methods is expected to result in more accurate data.

The first stage in data analysis techniques was to reduce data; data collected during the research process were grouped by using the coding technique, discarding unnecessary data, and organizing data in order to facilitate conclusion drawing. The second stage was to present data, whether in the forms of texts or tables. The third stage is to draw a conclusion by formulating a statement related to the research question. Meanwhile, the credibility of data was tested by using source triangulation.

\section{RESULT AND DISCUSSION}

Selection is the process of deciding which applicant best meets the needs of the organization. Some definitions of selection according to some experts are as follows: selection is the

Corresponding authors: Ira Irawati 
process of choosing from a group of applicants the individual best suited for a particular position [2]; process of collecting and evaluating information about an individual in order to extend an offer of employment [3]; some specific steps taken to determine which applicants will be admitted and which applicants will be eliminated [4]; specifically to the process of selecting from among all qualified applicants the person who will most likely best meet the needs of the organization for a specific position [5].

It can be said that selection process is a determining preliminary stage for the organization to obtain professional employee candidates who will hold particular positions. Selection is conducted not only for hiring new employees, but also for determining employees qualified to get job promotion.

The first stage of selection is to determine the expected competence criteria by considering the aspects of knowledge, skills, and abilities (KSA's) "knowledge as those information that allows an individual to perform functions that are based on theories, facts, and principles; skills address the demonstrated abilities or proficiencies, which are developed and learned from past work and life experience" [6].

After the competence has been compiled, the next stage is to determine the selection method. Some selection methods are usually used for determining the right man; structured interviews, cognitive ability test, biographical data, personality and integrity test, work sample test or assessment centers, unstructured interview, the "big five" personality traits [5].

Regulation of Head of the National Civil Service Agency (BKN) Number 23 Year 2011

Based on the opinion of some experts and the available studies on regulations, currently the contextual factor is much taken into consideration in recruitment. Selection and recruitment are not only emphasized on knowledge and skill or tangible ability but also on one's characters, behaviors, and habits called non-task-related factors which affect productivity and the achievement of the organizational goals [6].

Types of selection methods used to measure managerial competences at each echelon based on Regulation of the Head of State Civil Service Agency Number 23 Year 2011 are: 1) the psychological test is a test that uses various standardized psychological test measures to examine the tendency of intelligent potential and preferences of assesses which can used as prediction of success in a job; 2) the competence interview is an assessment that uses structured interviews arranged based on the competence requirement of the job to be occupied; 3) the competence questionnaire is an assessment that uses a list of questions arranged based on the competence requirement of the job to be occupied; 4) simulation is a measure that uses complex problems describing real situation and condition which may arise in everyday tasks/works.
Table 1. Types of Selection Measures of Echelons I-IV

\begin{tabular}{|c|c|c|c|c|c|}
\hline Echelon & Method & $\begin{array}{c}\text { Psycholo } \\
\text { gical } \\
\text { Test }\end{array}$ & $\begin{array}{c}\text { Competence } \\
\text { Questionnair } \\
\text { e }\end{array}$ & $\begin{array}{c}\text { Compet } \\
\text { ence } \\
\text { Intervie } \\
\text { w } \\
\end{array}$ & $\begin{array}{c}\text { Simula } \\
\text { tion }\end{array}$ \\
\hline I & $\begin{array}{l}\text { Assessment } \\
\text { Center }\end{array}$ & $\sqrt{ }$ & $\sqrt{ }$ & $\sqrt{ }$ & Min 2 \\
\hline II & $\begin{array}{l}\text { Assessment } \\
\text { Center } \\
\end{array}$ & $\sqrt{ }$ & $\sqrt{ }$ & $\sqrt{ }$ & Min 2 \\
\hline III & $\begin{array}{c}\text { Quasi } \\
\text { Assessment } \\
\text { Center } \\
\text { (3 measures) }\end{array}$ & \multicolumn{3}{|c|}{$\begin{array}{l}\text { Choosing } 2 \text { among 3: } \\
\text { - Psychological Test and } \\
\text { Competence Questionnaire; or } \\
\text { - } \quad \text { Psychological Test and } \\
\text { Competence Interview; or } \\
\text { - Competence Questionnaire and } \\
\text { Competence Interview }\end{array}$} & Min 1 \\
\hline IV & $\begin{array}{l}\text { Quasi } \\
\text { Assessment } \\
\text { Center } \\
\text { (2 measures) }\end{array}$ & \multicolumn{3}{|c|}{$\begin{array}{l}\text { Choosing } 1 \text { among 2: } \\
\text { - } \quad \text { Psychological Test; or } \\
\text { - } \quad \text { Competence Questionnaire; or } \\
\text { - } \quad \text { Competence Interview; }\end{array}$} & Min 1 \\
\hline
\end{tabular}

In the selection of Echelons III the assessment team must determine 3 measures, and as for Echelons IV, the team must determine 2 measures. Therefore, the competence assessment team must choose which method is efficient to measure competences for Echelons II and IV. For this reason, determination of an appropriate selection method is usually conducted based on some considerations, such as validity, reliability, and the cost spent. Meanwhile, measures which are able to more accurately predict the future performance of employees are based on validity of the selection method. Comparison of the validity of selecting methods proposed by some experts is as follows:

Table 2. Comparison of The Validity of Selection Methods

\begin{tabular}{|c|c|c|c|}
\hline \multirow[t]{3}{*}{ Method } & \multicolumn{3}{|c|}{ Validity } \\
\hline & \multicolumn{2}{|r|}{ Score } & Criteria \\
\hline & [7] & [8] & [8] \\
\hline Structured interviews & 0.51 & 0.48 to 0.67 & High \\
\hline \multirow{3}{*}{$\begin{array}{l}\text { Cognitive ability test/job } \\
\text { knowledge test }\end{array}$} & 0.48 & 0.44 to 0.47 & High overall \\
\hline & & 0.60 & $\begin{array}{ll}\text { High for } & \text { very } \\
\text { complex jobs } & \\
\end{array}$ \\
\hline & & .024 & $\begin{array}{l}\text { Low for the least } \\
\text { complex jobs }\end{array}$ \\
\hline Biographical data & 0.35 & 0.36 & Medium \\
\hline $\begin{array}{l}\text { Personality and integrity } \\
\text { test }\end{array}$ & 0.41 & 0.31 to 0.37 & Medium \\
\hline Work sample test & 0.54 & 0.24 to 0.43 & Low to Medium \\
\hline Assessment centers & 0.37 & 0.24 to 0.43 & Low to Medium \\
\hline Unstructured interview & 0.38 & 0.23 to 0.37 & Low to medium \\
\hline GMA test & 0.51 & & \\
\hline $\begin{array}{l}\text { Conscientiousness test/ } \\
\text { the "big five" personality } \\
\text { traits }\end{array}$ & 0.31 & 0.00 to 0.15 & Low \\
\hline Job tryout procedure & 0.44 & & \\
\hline Peer ratings & 0.48 & & \\
\hline $\begin{array}{l}\text { Training and Experience } \\
\text { behavioral consistency } \\
\text { method }\end{array}$ & 0.45 & & \\
\hline Reference test & 0.26 & & \\
\hline Job experience (years) & 0.18 & & \\
\hline $\begin{array}{l}\text { Training and Experience } \\
\text { point method }\end{array}$ & 0.11 & & \\
\hline Years of education & 0.10 & & \\
\hline Interest & 0.10 & & \\
\hline Graphology & .02 & & \\
\hline Age & .01 & & \\
\hline
\end{tabular}


Referring to the research result proposed by Hermelin and Robertson [7] and Schmidt and Hunter [8], there are differences in the result of validity of each selection method. There is a change in the validity of selection methods in a period of 4 years based on the result of both researches. Schmidt and Hunter [8] stated that the method with the highest validity score is structured interview. Meanwhile, according to Hermelin and Robertson [7] structured interview is the method with the second highest validity score. The method with the highest score is the work sample because it is able to examine an applicant's skill on a work-related task through direct assessment; hence the performance shown may approach the actual performance.

The choice of measures in selection of echelons III and IV based on Regulation of the Head of State Civil Service Agency Number 23 Year 2011 may refer to Table 1. Validity of the score of interviews and psychological test is relatively the same. However, psychological tests have some advantages compared to interviews and competence questionnaires. Based on the competence assessment experienced by the Regency Government of A and the Regency Government of B, the cost of psychological tests is lower than that of interviews. The experience of some experts also has revealed that GMA (also called general cognitive ability and general intelligence) can be used for all jobs [8]. Therefore, apart from the element of validity, the determination of types of competence tests must also consider other elements, such as the cost of selection owned by the public organization and the flexibility of the measures towards various kinds of jobs.

The advantage of interviews is the ability to elicit deeper information and the ability to directly see one's response to the needed information, but the cost of interviews is higher than that of psychological tests and competence questionnaires. Meanwhile, the advantage of competence questionnaires is that its cost is lower than psychological tests and competence interviews, but a constraint occurs in the preparation process of questionnaires, in which assessors must conduct a preliminary research on the type of jobs and the job risk of the position to be applied for to identify the expected competence. Usually the result of competence questionnaires is not valid enough to describe employees' competence. Hence, the choice of competence questionnaires as complementary measures can be suggested, but they are not suggested as a single measure. The reason is that competence questionnaires must be validated with other measures.

There is no simple rule of thumb for which or how many test use. Although some methods have greater validity, several are necessary at a minimum to provide the degree of assurance appropriate for such an important decision. Interviewing and reference checks are major responsibilities for the hiring manager and involve discretion. Although this discretion is important, unstructured interviews and haphazard reference checks frequently result in low validity, wasted resources, frustrated candidates, and illegal practices (MSPB in Berman et al, 2010).

After determining the main measure, the next step is to choose the measure in simulation. The crucial factor of all types of measures is the design of questions that must accord with types and levels of the expected competences. Therefore, the determination of types of simulation is begun with identification of types and levels of the expected competences for a job by conducting interviews with the job holder, superiors, or peers.

The technique for choosing measures for simulation stated in Regulation of the Head of State Civil Service Agency Number 23 Year 2011 depends on the type competence to be measured and availability of time for assessment. There are 6 types of main competences which are usually measured, analytical thinking (AT), planning and organizing (P\&O), relationship building (RB), customer service orientation (CSO), decision making (DM), and team leadership (TL). Meanwhile, the availability of time for assessment can be measured with the job weight of the assessor at the stage of planning and implementation of each type of measures according to the experience in conducting assessment in the Regency Government of A and the Regency Government of B.

Table 3. Types of Simulation Based on Measured Competence

\begin{tabular}{|l|l|l|}
\hline \multicolumn{1}{|c|}{$\begin{array}{c}\text { Tyoes of } \\
\text { Simulation }\end{array}$} & \multicolumn{1}{|c|}{ Definition } & \multicolumn{1}{c|}{$\begin{array}{c}\text { Types of Measured } \\
\text { Competence }\end{array}$} \\
\hline In Tray & $\begin{array}{l}\text { Simulation technique in which } \\
\text { assesses are assigned to respond to } \\
\text { the problem in the question file } \\
\text { given }\end{array}$ & $\begin{array}{l}\text { AT, P\&O, RB, CSO, } \\
\text { DM, TL }\end{array}$ \\
\hline Proposal Writing & $\begin{array}{l}\text { Simulation technique in which } \\
\text { assesses make a written proposal }\end{array}$ & AT, P\&O, RB, CSO \\
\hline Presentation & $\begin{array}{l}\text { Simulation technique in which } \\
\text { assesses present information or a } \\
\text { problem and solution to the case } \\
\text { systematically }\end{array}$ & $\begin{array}{l}\text { AT, P\&O, DM, RB, } \\
\text { CSO }\end{array}$ \\
\hline Case analysis & $\begin{array}{l}\text { Simulation technique in which } \\
\text { assesses are asked to solve a case }\end{array}$ & AT, P\&O, RB, CSO \\
\hline $\begin{array}{l}\text { Leaderless Group } \\
\text { Discussion } \\
\text { (LGD) }\end{array}$ & $\begin{array}{l}\text { Simulation technique which is } \\
\text { conducted by using one or some } \\
\text { problems to solve by assesses in } \\
\text { groups }\end{array}$ & AT, P\&O, DM, TL \\
\hline Role Play & $\begin{array}{l}\text { Simulation that assigns assesses to } \\
\text { play roles according to the } \\
\text { instruction }\end{array}$ & $\begin{array}{l}\text { AT, P\&O, DM, RB, } \\
\text { CSO }\end{array}$ \\
\hline
\end{tabular}

Source: Research Result, 2016-2017

Table 4. Types of Job Weight of Assessors in Each Type of Simulation

\begin{tabular}{|c|c|c|c|c|c|}
\hline \multirow{2}{*}{$\begin{array}{c}\text { Types of } \\
\text { Simulation }\end{array}$} & \multicolumn{2}{|c|}{$\begin{array}{l}\text { Preparation of } \\
\text { Questions }\end{array}$} & \multicolumn{2}{|c|}{ Implementation } & \multirow{2}{*}{$\begin{array}{l}\text { Score } \\
\text { Weight }\end{array}$} \\
\hline & $\begin{array}{l}\text { Stages of } \\
\text { Work }\end{array}$ & $\begin{array}{c}\text { Job } \\
\text { Weight }\end{array}$ & $\begin{array}{l}\text { Stages of } \\
\text { Work }\end{array}$ & $\begin{array}{c}\text { Job } \\
\text { Weight }\end{array}$ & \\
\hline In Tray & $\begin{array}{c}\text { Collecting } \\
\text { samples of } \\
\text { incoming and } \\
\text { outgoing } \\
\text { letters, } \\
\text { verifying, and } \\
\text { preparing } \\
\text { questions }\end{array}$ & 1 & $\begin{array}{l}\text { Watching } \\
\text { assesses }\end{array}$ & 1 & 2 \\
\hline $\begin{array}{c}\text { Proposal } \\
\text { Writing }\end{array}$ & \multirow{2}{*}{$\begin{array}{c}\text { Interviews } \\
\text { with } \\
\text { stakeholders, } \\
\text { studying } \\
\text { actual issues } \\
\text { to determine } \\
\text { problem }\end{array}$} & 2 & $\begin{array}{l}\text { Watching } \\
\text { assesses }\end{array}$ & 1 & 3 \\
\hline Presentation & & 1 & $\begin{array}{l}\text { Observation } \\
\text { and } \\
\text { discussion } \\
\text { with } \\
\text { assesses }\end{array}$ & 3 & 4 \\
\hline
\end{tabular}




\begin{tabular}{|c|c|c|c|c|c|}
\hline \multirow{2}{*}{$\begin{array}{l}\text { Types of } \\
\text { Simulation }\end{array}$} & \multicolumn{2}{|c|}{$\begin{array}{c}\text { Preparation of } \\
\text { Questions }\end{array}$} & \multicolumn{2}{|c|}{ Implementation } & \multirow{2}{*}{$\begin{array}{l}\text { Score } \\
\text { Weight }\end{array}$} \\
\hline & $\begin{array}{l}\text { Stages of } \\
\text { Work }\end{array}$ & $\begin{array}{c}\text { Job } \\
\text { Weight }\end{array}$ & $\begin{array}{l}\text { Stages of } \\
\text { Work }\end{array}$ & $\begin{array}{c}\text { Job } \\
\text { Weight }\end{array}$ & \\
\hline $\begin{array}{c}\text { Case } \\
\text { Analysis }\end{array}$ & \multirow[t]{3}{*}{ statement } & 2 & $\begin{array}{c}\text { Watching } \\
\text { assesses }\end{array}$ & 1 & 3 \\
\hline $\begin{array}{l}\text { Leaderless } \\
\text { Group } \\
\text { Discussion } \\
\text { (LGD) }\end{array}$ & & 3 & $\begin{array}{c}\text { Observation, } \\
\text { recording } \\
\text { talk, making } \\
\text { verbatim of } \\
\text { discussion }\end{array}$ & 3 & 6 \\
\hline Role Play & & 3 & $\begin{array}{l}\text { Observation, } \\
\text { recording/ } \\
\text { noting down } \\
\text { roles }\end{array}$ & 3 & 6 \\
\hline
\end{tabular}

Source: Research Result, 2016-2017

* Weight : 3 = Hard, 2 = Moderate, 1 = Easy

Based on the explanation in Tables 1 and 2 In Tray occupies a special place because of some reasons. In tray is a type of simulation which is able to measure 6 types of expected competences and regarding the time needed to accomplish the job, referring to the job weight performed by the assessor, it is relatively shorter compared to other types of simulation. The choice of the type of simulation is adjusted to the type of competences to be measured and the factor of job efficiency (time, amount of resources, and cost).

\section{CONCLUSION}

The selection method with the highest validity is able to predict the future performance of employees. An appropriate choice of methods will help the organization to find the right man. Some methods are able to predict the future performance with a high level of validity, such as psychological tests and structured interviews. However, apart from the element of validity, the determination of types of competence tests must also consider other elements, such as the cost of selection owned by the public organization and the flexibility of the measures towards various kinds of jobs. Psychological tests have some advantages as a measure, both in cost and validity, compared to interviews and competence questionnaires. As for the choice of the method of simulation, In-Tray has advantages compared to other techniques of simulation because it is able to measure six types of competences and relatively easy to perform.

\section{REFERENCES}

[1] I. Fachrurezha, "Effect of Work Motivation on Employee Performance of Integrated Licensing Service Agency in Bekasi Regency" (Pengaruh Motivasi Kerja Terhadap Kinerja Pegawai Badan Pelayanan Perizinan Terpadu (BPPT) Kabupaten Bekas), Institut Manajemen Telkom, 2012.

[2] Mondy and Noe, Human Resource Management. Massachusetts: Allyn\& Bacon, 1991.

[3] R. D. Gatewood and H. S. Field, Human Resources Selection. Ohio: South Western Learning, 2001.

[4] S. Siagian, Human Resources Management (Manajemen Sumber Daya Manusia). Jakarta: Bumi Aksara, 2014.

[5] S. A. Larson and A. S. Hewitt, "Recruitment, Retention, Training Strategies," Rsearch Train. Cent. Community Living, 2012.

[6] D. E. Klinger, J. Nalbandian, and J. Llorens, Public Personnel Management: Context and Strategies. Pearson Education,Inc, 2010.

[7] S. A. Larson and A. S. Hewitt, "Recruitment, Retention, Training Strategies", 2012

[8] F. L. Schmidt and J. E. Hunter, "The Validity and Utility of Selection Methods in Personnel Psychology: Practical and Theoretical Implications of 85 Years of Research Findings," Psychol. Bull. Bull., vol. 124 , no. 2 , pp. $262-274,1998$. 